\title{
A FELÜLETI ÉRDESSÉG KIALAKULÁSÁNAK ELEMZÉSE TÖBBÉLŰ SZERSZÁMOK FORGÁCSOLÁSI MÛVELETEINÉL
}

\section{ANALYSIS OF FORMATION OF SURFACE ROUGHNESS IN CASE OF MULTI-BLADE CUTTING TOOL PROCESSES}

\author{
Ráczi Viktor ${ }^{1}$, Palásti-Kovács Béla ${ }^{2}$, Szalóki István ${ }^{3}$ \\ ${ }^{1}$ Óbudai Egyetem, Bánki Donát Gépész és Biztonságtechnikai Mérnöki Kar, H-1081 \\ Budapest, Népszínház u. 8. Telefon: +36-1-666-5470, raczi.viktor@gmail.com \\ ${ }^{2}$ Óbudai Egyetem, Bánki Donát Gépész és Biztonságtechnikai Mérnöki Kar, H-1081 \\ Budapest, Népszínház u. 8. Telefon: +36-1-666-5356,palasti@uni-obuda.hu \\ ${ }^{3}$ Óbudai Egyetem, Bánki Donát Gépész és Biztonságtechnikai Mérnöki Kar, H-1081 \\ Budapest, Népszínház u.8.Telefon:+36-1-666-5327, szaloki.istvan@bgk.uni-obuda.hu
}

\begin{abstract}
Present study shows the effects that form the significantly different microgeometry and surface roughness parameters compare to the theoretical surface in case of cutting processes with multi-blade cutting tools. Based on experimental tests the development of surface roughness is presented in case of drilling, face- and plain milling processes. It is proved that the production inaccuracy (run-out) of applied tools and the tool wear and cutting edge degradation in cutting processes causes amplitude, average and form deviation on machined microgeometry during the surface formation. It is pointed that the run-out of tool holder shaft - beside the cutting parameters and geometry - also plays significant role in formation of surface roughness.
\end{abstract}

Keywords: surface roughness, tool wear, tool accuracy, tool run-out

\section{Összefoglalás}

Jelen munkában bemutatjuk, hogy a többélü szerszámokkal dolgozó forgácsolási eljárások felületkialakításánál milyen hatások okozzák az elméletitől jelentősen különböző mikrogeometriát és az eltérő érdességi értékeket. Kísérleti példákon elemezzük az érdesség kialakulásának mechanizmusát fúrás, homlok- és palástmarás müveleteknél. Rámutatunk arra, hogy a felületképzés során az alkalmazott szerszámok gyártásakor keletkező pontatlanságok (ütések), valamint az él-elhasználódás alatt bekövetkező kopás és vágóél-változás a megmunkált felületen jelentős magassági, átlagos- és formai eltéréseket okoz. Rámutatunk arra, hogy a forgácsolási és geometriai adatok mellett a szerszámtartó tengely ütésének is meghatározó szerepe lehet a kialakuló felület érdességére.

Kulcsszavak: felületi érdesség, szerszámkopás, szerszám pontosság, szerszámütés

\section{Bevezetés}

Gyártás, minőség, müködés - egymástól elválaszthatatlan fogalmak. Minden olyan elöírás és probléma, amely a kapcsolódó alkatrészek gyártásánál felmerül, jelentős hatással lehet a müködésre.

Az Óbudai Egyetem Bánki Karán közel négy évtizede foglalkozunk a felületi mikrogeometria vizsgálatával, a megmunkáláskor kapott felületprofilok, topográfiák 
kiértékelésével, a forgácsolt felület és a felületet kialakító szerszámmal közvetlen kapcsolatával, egymásra hatásával [1]. Számos forgácsolási eljárást (esztergálás, gyalulás, fúrás, marás, köszörülés, szuperfiniselés, stb.) [2] vizsgáltunk meg abból a célból, hogy feltárjuk az egyes megmunkálások mikrogeometriai jellegzetességeit (1. ábra), az érdesség kialakulásának mechanizmusát.

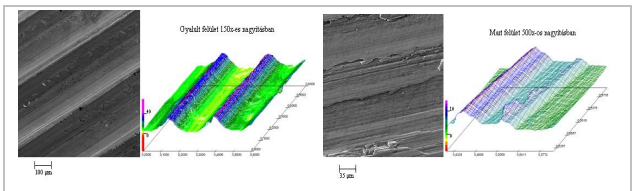

1. ábra. Gyalult, ill. mart felület topografikus és elektronmikroszkópos képe

Vizsgálatainkból összegezhetö, hogy egy adott megmunkálással elöállított felület sem méréstechnikai, sem gyártási szempontból nem tekinthető homogénnek. Ugyanazon felületet jellemzö, egymáshoz közeleső mérésekből kapott érdességi paraméterek jelentős eltérést mutathatnak, akár elérhetik a 70-100\%-ot is [1].

$\mathrm{Az}$ előző évi konferencián részletesen elemeztük az esztergálással kapott felületi mikrogeometria létrejöttét. Megállapítottuk, hogy a szerszám kopása és annak időbeli változása jelentősen visszahat a megmunkált felületre (2. ábra). Mindez a felület érdességét alakító csúcshátlap kopási jellegzetességeire vezethető vissza.

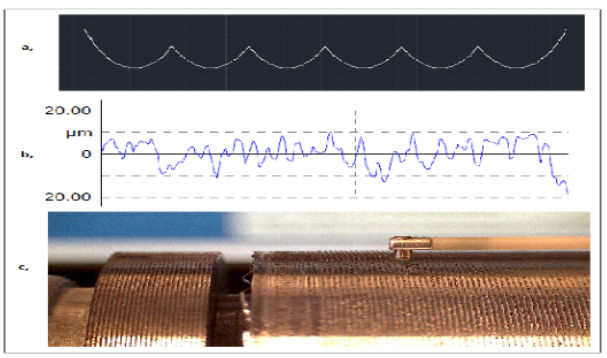

2. ábra. Esztergált felület mikrogeometriai jellegzetességei és az elméleti profil
Megváltozik a mikrogeometriai profil jellege, az általánosan ismert $\mathrm{Ra}$ és $\mathrm{Rz}$ érdességi paraméterek értékei pedig akár 200-300\%-os eltérést is mutathatnak a szerszám éltartama alatt [3].

Jelen munkánkban a jellegzetes többélü szerszámok felületalakítását vesszük vizsgálat alá, s elemezzük a kialakuló mikrogeometriára ható tényezőket.

\section{A megmunkálógép és a szerszá- mok állapota, pontossága}

Többélủ szerszámoknál nagyon fontos figyelembe venni a szerszámgép pontosságát. A kísérletekhez alkalmazott Mazak Nexus 410A-II megmunkáló központ bevizsgálása (3. ábra) azt mutatta, hogy az ISO elóírásokat (max. $3 \mu \mathrm{m}$ ), szerszám nélkül teljesíti ugyan, de a bemért $2 \ldots 3 \mu \mathrm{m}$ ütések finomfelületi megmunkálásnál már jelentős hibákat okozhatnak.
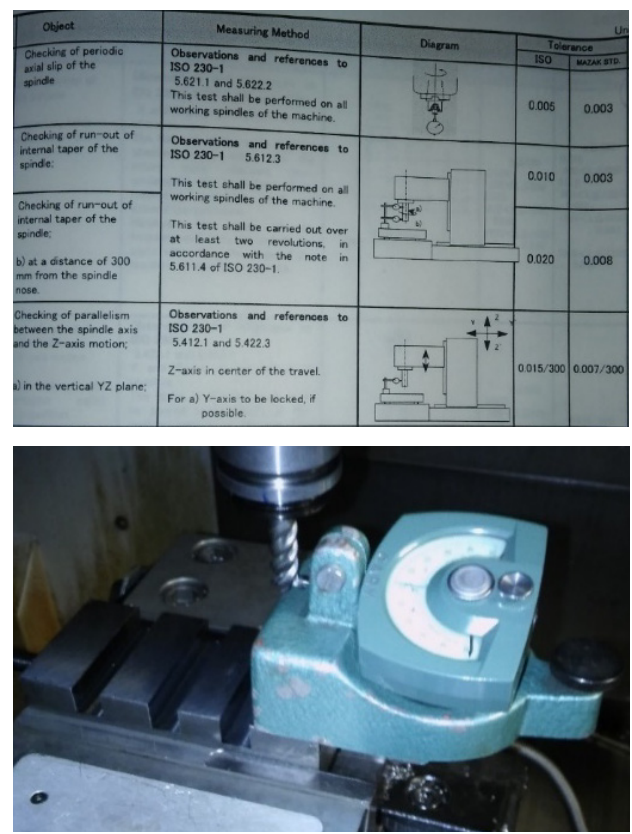

3. ábra. A Mazak gép és a szerszám együttes hibájának bemérése finomtapintóval 
A szerszámok bemérése további, még jelentősebb ütéseltérésekre világított rá:

Walter gyártmányú DC170 típusjelü ø8 mm csigafúrónál az 1 . fog ütése $5,5 \mu \mathrm{m}$, a 2. fog $-2 \mu \mathrm{m}$ volt, így feltételezhetö, hogy döntően az 1. fog alakítja majd a felületet.

A Seco R220... négy fogú homlokmarónál az 1 . fog ütése $0 \mu \mathrm{m}$, a 2 . fog $+18 \mu \mathrm{m}$, a 3. fog $-27 \mu \mathrm{m}$, a 4 . fog $+8 \mu \mathrm{m}$, így itt az valószínüsíthető, hogy a felület végső alakításában döntően a 2 . és a 4 . fog vesz részt.

A palástmaráshoz alkalmazott Walter H312... ujjmarók egyes fogai is jelentős ütéssel, 0-6 $\mu \mathrm{m}$ rendelkeztek (lásd 4. ábra).

\begin{tabular}{|r|c|c|c|}
\hline Fog & Maró-1 & Maró-2 & Maró-3 \\
\hline $\mathbf{1}$ & 0 & 0 & 0 \\
\hline $\mathbf{2}$ & $-1,5$ & 6 & 2,5 \\
\hline $\mathbf{3}$ & 3 & 4,5 & 3,5 \\
\hline $\mathbf{4}$ & $-1,5$ & 5 & 0 \\
\hline
\end{tabular}

4. ábra. Az ujjmarók fogainak ütése $(\mu \mathrm{m})$

Itt is feltételezhető a legnagyobb pozitív ütéssel rendelkező fog dominanciája.

\section{Fúrt felület kialakulása a forgá- csolás folyamatában}

A DC170 fúróval végzett forgácsoláskor az elméleti érdesség számításában döntően a fóél és mellékél helyzetét jellemző $\kappa_{\mathrm{r}}$, ill. a $\kappa_{\mathrm{r}}$ ' szögek vesznek részt $\left(\mathrm{r}_{\varepsilon}=0\right)$, (5. ábra).

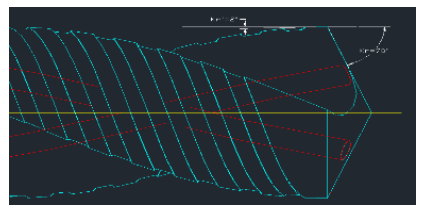

5. ábra. A fúró dolgozó élszögei $\left(\kappa_{r}=70^{\circ} ; \kappa_{r}{ }^{\prime}=2^{\circ}\right)$

Az itt alkalmazható elméleti képlet:

$$
R_{\text {elm }}=f_{z} \cdot \frac{\operatorname{tg} \kappa_{r} \cdot \operatorname{tg} \kappa_{r}{ }^{\prime}}{\operatorname{tg} \kappa_{r}+\operatorname{tg} \kappa_{r}{ }^{\prime}} \cdot 1000[\mu m]
$$

A valós érdesség alakulásánál már csak az egyik fog dominál, $s$ így az $\mathrm{f}_{\mathrm{z}}$ fogankénti elötolás helyett az f hatásával, illetve a sarokkopás és a forgács felületroncsolásával is [4] számolni kell (6. ábra).
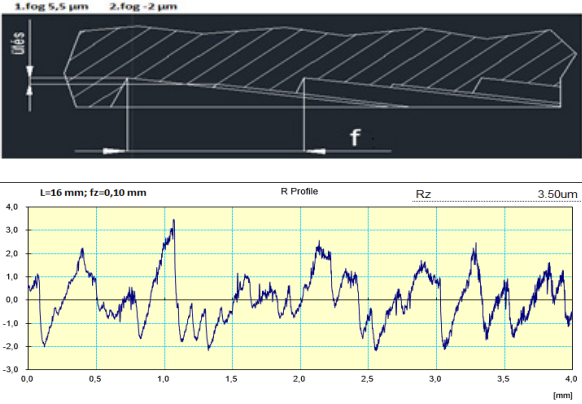

6. ábra. Az ütéssel rendelkezö csigafúró elméleti profilja és a valós profil

\section{A homlokmart felület kialakulá- sa}

Homlokmarásnál a lapkák geometriája, homlokütése és járulékosan természetesen a szerszámgép föorsójának pontossága hat a kialakuló felületi érdességre. Mivel a marólapka itt $\mathrm{r}_{\varepsilon}=0,8 \mathrm{~mm}$ csúcssugárral és kis $\kappa_{\mathrm{r}}$ ' mellékél elhelyezési szöggel rendelkezik az alkalmazható elméleti képlet:

$$
R_{e l m}=\frac{\sin \kappa_{r} \cdot \sin \kappa_{r}{ }^{\prime}}{\sin \left(\kappa_{r}+\kappa_{r}{ }^{\prime}\right)} \cdot\left[f-r_{\varepsilon}\left(\operatorname{tg} \frac{\kappa_{r}}{2}+\operatorname{tg} \frac{\kappa_{r}{ }^{\prime}}{2}\right)\right] \cdot 1000[\mu m]
$$

A fogak ütése természetesen ezt megváltoztatja, s a legnagyobb homlokütésü fogak alakítják ki a valós felületet. Jól látható a 7. ábrán, hogy a legnagyobb ütésü két fog előtolás-nyoma dominál a szimulált és a valós profilképen.

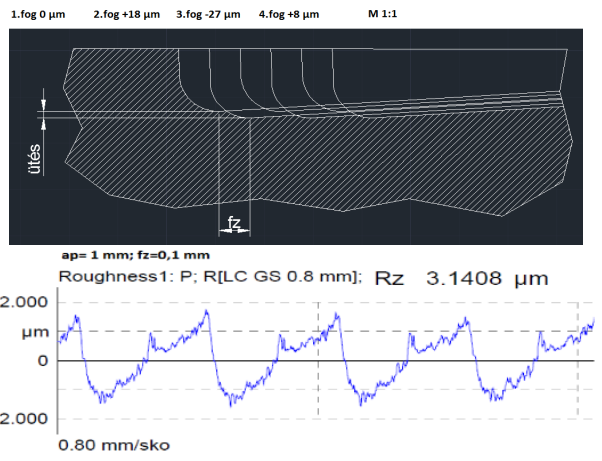

7. ábra. Az ütéssel rendelkezö homlokmaró elméleti és valós profilja 


\section{Palástmart felület kialakulása}

Esetünkben négy fog dolgozik egy körülfordulási ciklus alatt, s a szerszám geometriai hibái jelentősen befolyásolják a kialakuló felületi mikrogeometriát [5].

Egyetemünkön végzett kutatások itt is igazolják, hogy a felület messze nem egyenletesen alakul a marás során [5]. A mart felület érdességét többségében a legnagyobb ütésü fog alakítja ki (8. ábra)

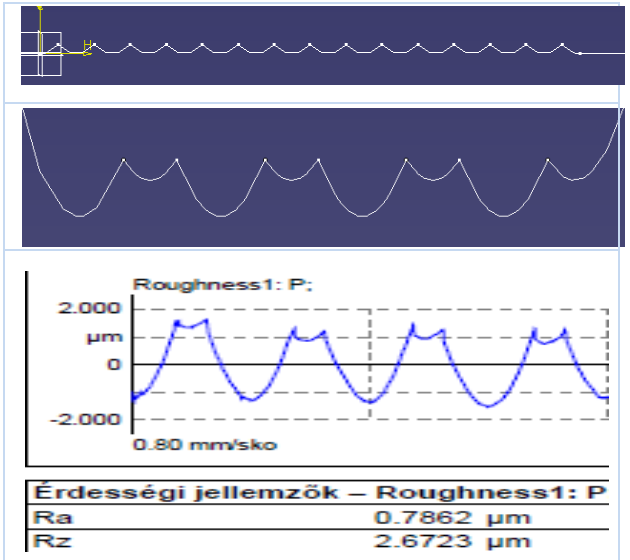

8. ábra. $A z S z-2$. 4 élü ujjmaró által elöállitott elméleti felületek ütés nélkül, ütésekkel és $a$ valós érdességmérés eredményei $\left(f_{z}=0,1\right.$ $\mathrm{mm})$, Rzelm=0,25 $\mu \mathrm{m}$, Rzvalós $=2,67 \mu \mathrm{m}$

A fogankénti elötolás $\mathrm{f}_{\mathrm{z}}$ hatása részlegesen vagy teljesen elvész, s szerepét döntően a fordulatonkénti előtolás $f$ veszi át. Ilyen esetben az elméleti érdesség az alábbi képletekkel számolható:

$$
R_{z}=\frac{f_{z}^{2}}{8 * R_{s z}}, \quad \text { és } \quad R_{z}=\frac{f^{2}}{8 * R_{s z}},
$$

ahol $\mathrm{R}_{\mathrm{sz}}$ - a marószerszám sugara.

A várható valós $R z$ egyenetlenségmagasság érdességi értékek a fenti képletek által meghatározott $(\min . . . \max )$ tartományban helyezkednek el, függően attól, hogy a forgácsoláskor adódó egyes fogütések milyen mértéküek.

\section{6. Összegzés, következtetések}

Egy adott gyártástechnológia alkalmazásakor a gép és a szerszám teljesítőképességét a forgácsleválasztás, a pontosság és a létrehozott felület érdessége tekintetében maximálisan ki kell használni.

E cél elérése érdekében ismernünk kell az adott technológia korlátait és lehetőségeit. Figyelemmel kell lenni arra, hogy a felületképzés a forgácsoló szerszám elhasználódási folyamata közben valósul meg és függ annak pontosságától.

A szerszám kopása és annak időbeli változása visszahat a megmunkált felületre, melytől megváltozik a mikrogeometriai profil jellege és mértéke.

Több élü szerszámoknál, így főként fúrásnál és marásnál a gépek és szerszámok eltérő gyártási pontossága, a szerszám éleinek ütése meghatározóan befolyásolja a forgácsoláskor kialakuló felületi érdességet. Ezért más technológiai paraméter $\left(\mathbf{v}_{\mathbf{c}}\right.$ forgácsolósebesség, f elötolás, a fogásmélység,...) érdességre való hatásának vizsgálatakor ezt figyelembe kell venni.

\section{Szakirodalmi hivatkozások}

[1] G. N. Tóth, Á. Drégelyi-Kiss and B. PalástiKovács: Analysis of microgeometrical parameters of cutting surfaces, Pollack Periodica, Vol. 8, No. 2, pp. 55-66 (2013)

[2] B. Palásti-Kovács, S. Sipos, Sz. Bíró: The Mysteries of the Surface First Part: The Characteristic Features of the Microgeometry of the Machined Surface, Acta Polytechnica Hungarica, Vol.11 No.5 2014. p.5-25

[3] J-E. Stahl, F. Schultheiss, S. Hagglund: Analytical and Experimental Determination of the Ra Surface Roughness during Turning, Procedia Engineering, 19 (2011) p. 349-356.

[4] I. Szalóki: Analysis of drilling surface microgeometry, 2nd Regional Conference Mechatronics in Practice and Education, Subotica, Serbia, (December 5-6. 2013). pp 111-114 ISBN 978-86-7892-565-8

[5] Ráczi V.: Az élpreparáció hatása nehezen forgácsolható anyagok marásakor, 2017.01.31. ÓE-BGK, Szakdolgozat. 